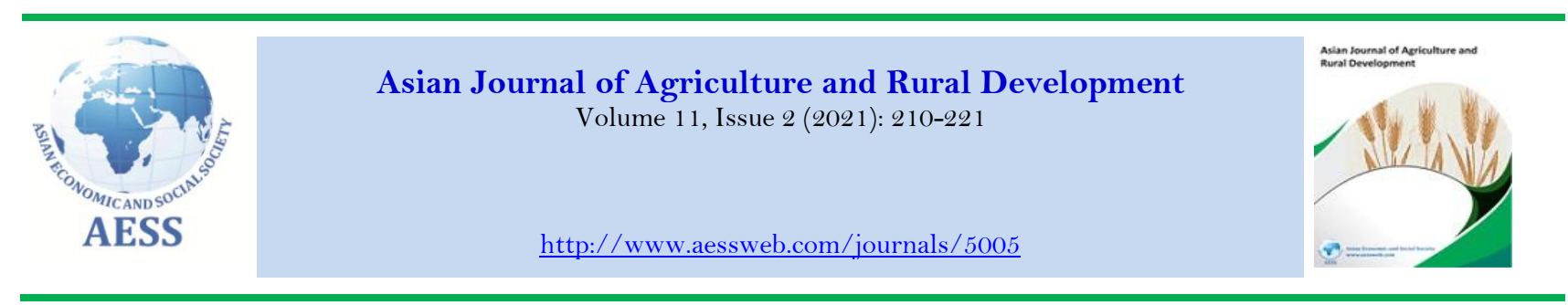

\title{
THE ROLE OF AGRICULTURAL EXTENSION IN DIFFUSION AND ADOPTION OF BIOLOGICAL CONTROL METHODS FOR TOMATO GROWERS IN VILLAGES OF MATROUH GOVERNORATE
}

\author{
iD Abdu Omran Mohamed" \\ iD Fekry Kamal Kamel ${ }^{\text {b }}$ \\ Yousria Ahmed Allam \\ Ismail Abdel-Malik Mohamed ${ }^{\mathrm{d}}$
}

\author{
${ }^{a .}$ Agricultural Division, National Research Center, Egypt. \\ ${ }^{b}$ Agricultural Extension and Rural Development Research Institute Agricultural \\ Research Centre, Egypt. \\ ${ }^{d}$ Department of Economic and Agricultural Cooperative Sciences, Higher Institute \\ for Agricultural Cooperation, Egypt. \\ هabdoomran666@yahoo.com (Corresponding author)
}

\section{ArticleHistory}

Received: 27 July 2020

Revised: 11 June 2021

Accepted: 2 July 2021

Published: 19 July 2021

\section{Keywords}

Agricultural Extension

Role

Diffusion

Adoption

Biological Control

Tomato

Knowledge

Growers

Process

Farmers

\begin{abstract}
This research aimed to define the role of agricultural extension in the process of Diffusion and adoption of biological control methods among tomato growers in Matrouh Governorate, Egypt, and also to define the relationship between their role in agricultural extension in Diffusion and adopting biological Control methods for tomato growers and some independent variables. The research was conducted in Matrouh Governorate using a random sample of 323 farmers, representing $16 \%$ of the total research cohort amounting to 2050 farmers; the data were collected using a questionnaire in September 2019. Data wereanalyszed using a statistical program, arithmetic mean, and the simple correlation coefficient of Pearson $(r)$. The results are also presented in tabular form using frequencies and percentages. The main results of the research are as follows:the majority of farmers $(82.97 \%)$ stated that the role of agricultural extension in diffusion and adoption methods of biological control among tomato growers was low, while $15.17 \%$ said that agricultural extension plays an intermediate role and $1.86 \%$ said it played a key role.There is a positivecorrelation at the 0.01 level of significance between the level of farmers' adoption of biological control methods as an dependent variable and each of the following independent variables: participation in local development organizations, social participation, satisfaction with life in the region, and attitudes towards agricultural innovations; and there is a positive correlation at the 0.05 level of significance with the levels of modernization and farmers' education.
\end{abstract}

Contribution/Originality: This study contributes to the existing literature by defining the role of agricultural extension in the process of diffusion and adoption of biological control methods among tomato growers in Matrouh Governorate, Egypt.

DOI: 10.18488/journal.ajard.2021.112.210.221
ISSN(P): 2304-1455/ISSN(E): 2224-4433

Howtocite: Abdu Omran Mohamed --- Fekry Kamal Kamel --- Yousria Ahmed Allam --- Ismail Abdel-Malik Mohamed (2021). The Role of Agricultural Extension in Diffusion and Adoption of Biological Control Methods for Tomato Growers in Villages of Matrouh Governorate. Asian Journal of Agriculture and Rural Development, 11 (2), $210-$ 221. 10.18488/journal.ajard.2021.112.210.221

(C) 2020 Asian Economic and Social Society. All rights reserved. 


\section{INTRODUCTION}

The agricultural sector is one of the most important production sectors and the main pillar of economic activity in Egypt. Agriculture is considered one of the most labour-intensive economic sectors, because the number of workers in the agricultural sector in 2012 reached approximately 6.4 million, representing $27.1 \%$ of the total number of workers in Egypt For the year 2012, this sector contributed about 13.4\% of gross domestic product. Egypt is among countries whose food production does not meet the increasing needs of the population, as population growth rates always exceed growth rates in agricultural production and the population of Egypt increased from 18.97 million in 1947 to about 83.6 million in 2012, and over this period per capita agricultural land declined from 0.3 to 0.11 acres. Despite the efforts of the state to increase agricultural area, erosion and loss of agricultural land is often equal to total reclaimed land, withloss of more than 750 thousand acres of the best types of agricultural land in the Delta and Lower Egypt during the second half of the last century(Central Agency for Mobilization and Statistics, 2015).

In addition, the production of vegetables in Egypt is considering an essential aspect of food production.

Agricultural extension can play an effective role in improving crop quality and increasing productivity, as vegetable crops are considered among those of economic importance because they fall within the realm of intensive agriculture, which allows a higher profit margin than traditional crops. The area undervegetables in Egypt at the present time is about 1.5 million acres, and it produces more than 17 million tons for local consumption, export, manufacture, and seed. We need to double this area as a result of an increasing population, because vegetable crops are necessary for local consumption and an important source of vitamins and mineral elements, as well as an important source for the establishment of many agricultural industries, the most important of these being tomato(International Potato Center, 2015). Therefore, efforts being made in Egypt to grow vegetable crops should be a high priority due to their economic importance as one of the main components of national agricultural income, where the annual income from the production from vegetable crops in 2015 amounted to 6,092,967 pounds, or $36.62 \%$ of the average annual agricultural income of 21,934,681 pounds(Central Administration of Agricultural Economics, 2018).The tomato crop is considered one of the most important vegetables crops in terms of annual cultivated area, which amounted to about 344,562 acres, and total production reached 123,368,860 tons in 2015 as a result of effective extension programs and services to improve the level of productivity (Central Administration of Agricultural Economics, 2018). Although the state has paid considerableattention to tomato crops, it is noted that there are many diseases and insect pests affecting tomato, which leads farmers to use many agricultural pesticides that may expose the fruit to various health problems.Despite all the efforts and extension services provided in this field, there are still considerable failings in the effectiveness of these activities and services for tomato growers, such as in Matrouh Governorate, where farmers face many difficulties and problems that are reflected in their misuse of agricultural pesticides. The world has now turned towards the use of organic farming technology as the total global cultivated area reaches about 25 million hectares, and sales volume reached US $\$ 40$ billion in 2005 , for the following reasons. The consumerwishes to buy safe food that does not contain pesticide residues or chemicals. Reduction in environmental degradation, preservation of soil fertility, and preservation of biological diversity are all now key issues, in addition to a profitable financial return for organic farming (Hamdi, 2006). Therefore, Egypt has adopted this trend towards clean agriculture based on the use of organic, biological fertilizers and biological control of insect pests and diseases that affect various agricultural crops (Bahloul, 1999). Therefore, Egypt has adopted the trend towards clean agriculture based on the use of organic and biological fertilizers and biological control of insect pests and diseases that affect various agricultural crops (Bahloul, 1999): the area of organically grown crops has soared from 11.8 thousand fedans in 1999 to 43.2 thousand in 2004; theCenter for Organic Agriculture in Egypt was established as an inspection center and an article was added to allow for the regulation of such crops. Modern agriculture depends on several foundations, including: integrated resistance, especially vital ones, in eliminating agricultural pestsusing sexual attractant pheromones to predict the numbers of pests, yellow adhesive traps, and microbiocides (bacteria, fungi, and viruses); all of these alternatives came into effect under the concept of "biological resistance". Egypt has become one of the main canters of production of organic agriculture and has attracted the attention of importers from Europe and around the world, with many Egyptian companies starting to enter this field - the number of companies working in the field of organic agriculture has now reached 40. Egypt now produces a large number of organic crops covering vegetables, fruits, cereal crops, and medicinal and aromatic plants (Tolba, 2008), so organic agriculture should receive more attention to overcome the problems of using pesticides. Biological control is considered one of the most important elements of the pest control department. Biological control means working to encourage and increase the natural enemiesof pests in the same environment, or importing these vital enemies and trying to localize them and spread them widely to reduce pest reproduction. The biological enemies of pests include parasites and predators(Abdou, Mohammed, \& Allam, 2016).

Biological control also depends on the use of what is known as biocides, which are among the most important elements of microbiocides and include various pathogens (fungi, bacteria, viruses, nematodes, and protozoa); pesticides resulting from fermentation processes for actinomycetes naturally present in the soil;pheromones;pesticides extracted from plants; and plants genetically modified to control pests (Al-Huneidi, Ahmed, \& Fayyad, 2004).It is known that plant pathogens cause pathological symptoms in cereal and horticultural crops, resulting in significant losses in productivity and quality that affect farm incomes, and consequently the national economy and exports. Therefore, plant disease control must be supported by modern methodsratherthan by the use of chemicals and pesticides as much as possible, which has a harmful effect on both humanand animal health, in addition to harming the environment and causing pollution of air , water, and soil (Egyptian Plant Pathology Society, 1996). From the above, it is clear that it is important to study the role of agricultural extension in adoption innovations because this works as a link between research and farmers, where the problems of farmers are transferred 
to the research authorities, and here the technology becomes the result of scientific research in solving farmers' problems, as they are the recipients and users of the technology (Omar, 1992).

The stages of diffusion and adoption of agricultural innovations are seen among farmers. Through several steps that are summarized in providing knowledge about the innovations and how to use them correctly, and getting farmers to make a decision to experiment by showing its benefits to them, providing the information necessary for them toimplement, providing the necessary capabilities for that, and helping farmers to evaluate the results of their application of the innovations so that they can make a decision to adopt,Flegel (1990) and Yousria, Allam, and Mohamed (2016) stated that it is important to supportproducers in the desert environmentwith its difficult conditions, by providing mechanization services, reservoirs and surface wells for water irrigation, scheduling bank debts,and helping them adopt agricultural innovations.

In the light of the previous elements, this research seeks to answer the following questions:

- What is the role of agricultural extension in the diffusion and adoption of biological control methods among tomato growers?

- What is the relationship between the level of the role of agricultural extension in diffusion and adoption of biological control methods for tomato growers and some of the independent variables?

\section{RESEARCH OBJECTIVES}

According to the research problem previously presented, the following objectives were elaborated:

First: Determine the role of agricultural extension in diffusion and adoption of biological control methods among tomato growers through the following activities:

1a. The degree to which agricultural extension' activities provide knowledge about the biological control methods between tomato farmers, and clarify how to use them correctly.

1b. The level of agricultural extensionactivities engaging farmers in deciding to try these methods by clarifying their advantages.

1c. The level of agricultural extension activities providing the information necessary for applying these methods.

$1 \mathrm{~d}$. The level of agricultural extension activities providing the necessary capabilities to implement biological control methods among tomato growers.

1e. The level of agricultural extension assisting tomato growers in evaluating the results of their application of biological control methods so that they can make a decision to continueand adopt.

Second: Determine the correlation between the degree to which biological control methods are adopted between tomato growers as a dependent variable and certain independent variables.

\section{RESEARCH HYPOTHESIS}

To achieve the second goal, the following research hypothesis was formulated: there is a significant correlation between the degree to which tomato farmers adopt biological control methods as a dependent variable, and some of the following independent variables: age, education level, area of agricultural tenure, number of years of experience in agricultural work, area planted with tomato crop, level of modernization, level of opinion leadership, participation in local development organizations, level of informal social participation, level of satisfaction with life in the region, and prevalence ofattitudes toward agricultural innovations.

\section{RESEARCH METHOD}

\subsection{Procedural Definitions}

Definition of biological control: it is the action of living organisms (natural enemies) to reduce the intensity of insectpest numbers in either animals or plants to the extent of economic damage limits.

\subsection{Search Area}

The northwest coast of Matrouh is considered one of the most important new and promising areas in the field of horizontal agricultural development, because Matrouh Governorate is one of the largest governorates in the Republic in terms of area, with a length of approximately $450 \mathrm{~km}$ from Burj Al Arab to the Libyan border, and with a depth of $400 \mathrm{~km}$ (Matrouh Governorate, 2016). Most of the area is arable, and almost all agricultural lands are used to maintain irrigation through rain except for Siwa, Hammam, and the irrigated part of El Alamein The city of MarsaMatrouh is the capital of the governorate and is located $286 \mathrm{~km}$ west of Alexandria, $240 \mathrm{~km}$ from the Egyptian-Libyan border. The governorate consists of eight administrative centers, with the centers of Al-Hamam, Al-Alamein, and Al-Dabaa located east of the city of MarsaMatruh, the capital,distances of 226.5, 184, and 138 km, respectively, while the centers of Al-Nujaila, SidiBarani, Salloum and Siwa are at distances of 75, 126, 215, and $301 \mathrm{~km}$, respectively from MarsaMatrouh ; Among the largest centers where tomatoes grown is the center of $\mathrm{Al}-$ Hamam, where an area of 11,927 acres is cultivated, representing $93.4 \%$ of the tomato area in 2018 in Matrouh Governorate (The Arab Republic of Egypt, 2018). Among the largest centers where tomatoes grown is Al-Hammam center, where an area of 11,927 acres is cultivated, representing 93.4\% of the tomato area in 2018 in Matrouh Governorate (The Arab Republic of Egypt, 2018). 


\subsection{Research and Sampling}

A comprehensive study was undertaken, sampling tomato growers in the Al-Hammam center in Matrouh Governorate, where six societies plant 11,927 acres of tomato; and the largest three associations were chosen in terms of area: Abu Shabina, with an area of 3600 acres and 750 farmers, and Al-Hammam center with an area of 350 acres and 700 farmers, and Al-Amed in an area of 3300 acres and 600 farmers, where the area of the three associations represents $86.4 \%$ of the area planted with tomato in the center of Al-Hammam, and the total number of tomato crop growers selected among the three associations was 2050.

The sample size was determined using the equation of Krejcie and Morgan (1970), as 323 tomato growers were included, representing $16 \%$ of the total. Using the same percentage, the number of farmers was chosen in a simple random way from three associations (Directorate of Agriculture in Matrouh, 2018, unpublished data).

Table-1. Distribution of tomato growers among the three largest associations.

\begin{tabular}{l|l|c|c|c}
\hline No. & Association & $\begin{array}{c}\text { Area planted with } \\
\text { tomato(feddans) }\end{array}$ & $\begin{array}{c}\text { Total number } \\
\text { (Population) }\end{array}$ & $\begin{array}{c}\text { Sample } \\
\text { (16\% of population) }\end{array}$ \\
\hline 1 & Al-Hammam & 3500 & 700 & 110 \\
\hline 2 & 15 May & 802 & - & - \\
\hline 3 & Al-Amed & 3300 & 600 & 95 \\
\hline 4 & Abu Shabina & 3600 & 750 & 118 \\
\hline 5 & Alamfonush & 400 & - & - \\
\hline 6 & Abnaa al mostakbl & 325 & - & - \\
\hline \multicolumn{2}{r|r|}{ Total: 11,927} & 2050 & 323 \\
\hline
\end{tabular}

\subsection{Data Collection Methodsand Tools}

To achieve their research objectives, the questionnaire was designed to include a set of questions related to the role of agricultural extension in the diffusion and adoption of biological control methods between tomato growers and the research independent variables. A pre-test of the questionnaire was conducted on a sample of 15 farmers from the 15 May Society, to verify clarity and ease of understanding of the phrases used by the respondents; the data were collected during September 2019 in a personal interview with the respondents.

\subsection{Data Quantitative Processing}

After completing data collection, the researcherstreated some data quantitatively by giving them values according to the scale used with each variable.

\section{Personal Variables}

1. Age:The age of the respondent is given as the nearest year at the time of data collection. The maximum and minimum ages of respondentswere 68 and 27 years, respectively .Respondents were divided according to age into three categories: $<41,41<55$ and $55+$ years.

2. Educationlevel: Thisparameter is the number of years of formal education for those who could read and write. One point was given for the illiterate farmer, two for those who could read and write; in regard to respondents who were officially educated, they were scoredaccording to the number of years of education and, by this, it was possible to derive scores indicating the respondent's level of education.

3. Agricultural tenure: Agricultural tenure as registered by the agricultural society and calculated in acres: maximum (20 acres), minimum ( 5 acres), and actual extent ( 15 acres. According to this parameter, farmers were divided into three categories of area: small ( $<10$ acres), medium (10-<15 acres), and large (15+ acres).

4. Number of years of agricultural work experience:Respondents were asked about the number of years of experience, expressed as a raw number, the maximum (35 years), minimum (5 years), and actual extent (30years). The respondents were divided according to range into three categories: little experience (less than 15 years), medium experience (15-25 years), and significant experience (25 years + ).

5. Area planted with tomato: The size of the area on which the respondent cultivates tomato. The respondents were divided according to that variable to the nearest acreageinto the following categories: maximum (7 acres), minimum ( 1 acre), and actual range ( 6 acres). The respondents were divided according to range into three categories: small (less than 3 acres), medium (3to less than 5 acres), and large ( 5 acres + ).

6. Number of years of tomato Cultivation: The number of years in which the farmer planted tomato; this variable was calculated by raw numbers as maximum (25 years), minimum (10 years), and actual extent (15 years). The respondents were divided according to range into three categories: little experience (less than 15 years), medium experience (from 15 to less than 20 years), and significant experience (20 years + ).

7. Degree of modernization: The application and use by the researcher of new technologies; this variable was measured on a scale of six: agree, neutral, and disagree, scored 3, 2, and 1, respectively, for a positiveand vice versa for negative. The maximum (18), minimum (6), and actual range (12) of the three categories are: low (less than 10), medium (10 to less than 14), and high (14+).

8. Self-assessed degree of leadership: Self-assessment by respondents of their being a source of agricultural information and guidance compared to other farmers; this consists of 6 indicators indicating the degree of leadership among therespondents, withscoring of 3,2, and 1 for agree, neutral, and disagree, respectively. The maximum was 
(18), minimum (6), and actual range (12); respondents were divided according to range into three categories: low level of leadership (less than 10), medium level (from 10 to less than 14), and high (14+).

9. Participation in local development organizations: Attendance at meetings of these organizations. Four grades were given to the chairman of the board of directors, three grades for a member of the board of directors, two grades for a member of the committee,one for a regular member, and zero for non-participation;two grades were given to those attending meetings and activities and zero for those who do not attend.: maximum (14), minimum (zero), and actual extent of the degree of respondents' participation in local development organizations (14). Respondents were divided according to range into three categories: low participation (less than 5), medium (from 5to less than 10), and high $(10+)$.

10. Degree of informal social participation: This variable was measured quantitatively on the basis of measuring the respondent's participation in five of the most important social activities in the region, through four responses in front of each that determines the degree of participation: always participating, sometimes participating, rarely participating, and not participating, and those responses were given grades $(4,3,2$, and 1) respectively, and the scores obtained by the respondent were combined to reflect the total score for informal social participation: maximum (20), minimum (5), and actual extent of the degree of respondents' participation in informal social events (15).Respondents were divided according to range into three categories: low participation (less than 10 degrees), medium participation (from 10 to less than 14), and a high participation(14+).

11. Degree of satisfaction with life in the region: This variable was measured on a scale of 8 , each of which has three responses: agree, neutral, and disagree. The maximum score according to this scale was (24), minimum (8), and theoretical extent in terms of their degree of satisfaction with life (1),and was divided into three categories: low degree of satisfaction (less than 13), medium degree of satisfaction (from 13 to less than 18), and high degree of satisfaction $(18+)$.

12. Attitude towardsagricultural innovation: Using a ten-point scale consisting of three responses, agree, neutral, and disagree. Responses were scored between 3 and 1 in the case of positive statements, and vice versa in the case of negative. The maximum according to this scale is 30 and the minimum 10, and the theoretical rangewas20. The respondents were divided into three categories: negative attitude towards innovations (less than 10), neutral attitude (from 10 to less than 14), and positive (14 degrees+).

\section{Dependent Variables}

The degree to which agricultural extension activities act in diffusionand adoption of biological control methods among tomato growers was measured using a scale that defines the role of agricultural extension in five dimensions using the following activities:

1a.The degree to which agricultural extension' activities provide knowledge about biological control methods among tomato farmers and how to use them correctly.

1b. The degree to which agricultural extension activities are adopted by farmers in deciding to try these methods by clarifying their advantages.

1c. The level of agricultural extension activities providing information necessary for the application of these methods. $1 \mathrm{~d}$. The level of agricultural extension activities providing the necessary capabilities to implement biological control methods among tomato growers.

1e. The level of agricultural extension assisting farmers in evaluating the results of their application of biological control methods, by explaining its usefulness to them so that they can make a decision regardingtheir continuingadoption.

1a. The degree to which agricultural extension activities provide knowledge about biological control methods to tomato growers, and clarification of how to use them correctly.

The role of extension was measured in the process of adoption of these methods through the use of a graduated scale: always, sometimes, rarely, or never, determining the level of carrying out biological control operations; scores of4, 3, 2 , and 1 were given, respectively, for the following;

\section{Dispersal Pheromones}

The views of farmers were investigated regarding the degree to which agricultural extension provided knowledge about biological control methods and how to use them in the correct way, through five statements:

-Work by creating an artificial smell to attract female butterflies.

-Spray it on plants or tie it to stems in tubes or rings in large areas.

-This leads to distracting males and their not meeting with females.

-Thus, the possibility of mating and laying of unfertilized.

- Do not hatch larvae, reduce infection.

\section{Sex-Attractant Pheromones}

The views of the farmers were investigated regarding the degree to which agricultural extension provided knowledge about biological control methods and how to use them in a correct way, through four statements

-Depends on creating the artificial smell of female butterflies.

-Put them in capsules inside special traps (water/paper).

-Catching male butterflies to reduce their mating opportunities.

-Leads to laying unfertilized eggs that do not hatch larvae. 


\section{Pathogenic Bacteria}

The farmers were asked about agricultural extension providing knowledge about biological control methods and how to use them in the correct way, through four statements:

- The pathogen is used to control pests.

- The bacteria are in the form of crystals.

- Once the insect has eaten these crystals, the walls of the bacteria will dissolve.

- The active substance is released as it causes the death of insects.

\section{Pathogenic Nematodes}

Farmers were asked about agricultural extension in regard to providing knowledge about how to use these properly, through the following statements:

1- Kills the insect within 48 hours, as nematodes breed on lesion.

2- Nematodes then search for other pests and so on until these pests are eliminated.

\section{Growth Regulators and Molting Hormones}

Farmers were asked about agricultural extension in regard to providing knowledge about how to use these properly, through the following statements:

1. Insectmolting hormones are used to eliminate them.

2. Thus, an imbalance in the life cycle of insects occurs, leading to their elimination.

4.6. Role of Agricultural Extension in Providing Knowledge about BiologicalControl Methods for Tomato, and Explaining How to Use These Correctly

Scoring in regard to the maximum level of providing knowledge about biological control methods for tomato, and explaining how to use these correctly (68), minimum (17), and range (17); farmers were divided into three categories: low (less than 34$)$, medium (34 to less than 51), and high (51+).

The level of agricultural extension to the farmers was measured regarding making a decision to experiment with biological control methods, the level of agricultural extension providing the information necessary for farmers to actually implement biological control methods, the degree to which agricultural extension provided the necessary capabilities to implement biological control methods, the level of agricultural extension assisting farmers to evaluate the results of their application of biological control methods and their benefit to them so that they can make a decision to continue implementation, and eventual diffusion and adoption in the same way.

\subsection{Role of Agricultural Extension inDiffusionand Adoption of Biological Control Methods among Tomato Growers}

The degree to which agricultural extension provides knowledge of biological control methods and how to use them properly, the degree to which agricultural extension invests farmers to make a decision to experiment with biological control methods, the degree to which agricultural extension provides the information necessary for farmers to actually implement biological control methods, the degree of agricultural extension providing the capabilities necessary to implement biological control methods, and the degree to which agricultural extension helps farmers evaluate the results of their application of biological control methods and their usefulness to them so that they can make a decision to continue implementation and diffusion and adoption.

Levels of each activity were converted to standard grades, the average of the total was calculated, and average percentage was calculated for activities a-e.

The levels of each extension activity were converted to standard scores to reflect the total score of the role of agricultural extension in the diffusionand adoption of biological control methods for tomato growers, through the following equation:

$$
\text { Overall score }=\underline{\text { the degree of each activity }- \text { arithmetic mean }}
$$

\section{standard deviation}

Through the previous five dimensions, the total level of the role of agricultural extension was obtained in diffusion and adopting methods of biological control among tomato growers. The level of the role of agricultural extension were limited to a maximum of 340 and a minimum of 85 ; thus the theoretical range (255) is divided into three categories: low (less than 170), medium (170 to less than 255), and high (255+).

\subsection{Statistical Analysis Tools}

These were used in analyzing the data for the statistical program devoted to social sciences, the arithmetic mean, and the simple correlation coefficient of Pearson $(r)$. The results are also presented using frequencies, percentages, and average percentages, in tabular form.

\subsection{Description of Research Sample (Table 2)}

More than a half of the respondents $(54.7 \%)$ were 55 years or more, the vast majority were educated $(75.2 \%)$, , and the vast majority of the agricultural tenure (58.6\%) was of 15 acres or more .More than half of the respondents number Experience agricultural (5.7\%) are from at 25 years and above,and The vast majority of the respondents The area planted with the tomato crop $(58.4 \%)$ from 3 - to Less than 5 acres ,and less than half of the respondents Number of years of tomato cultivation (39.7\%) less than 15 years,More than half of the respondents The degree of 
modernization (53.2\%) 14 degrees and more,and less than half of the respondents The degree of opinion leadership (41.9\%) 14 degrees and more,and less than half of the respondents Participation in local development - organization (43.3\%) from 5 - to less than 10 degrees,and The degree of informal social participation (45.8\%) from 10 - to less than 14 degrees, the respondents of the Degree of satisfaction with life in the region (48.9\%)18 degrees and more,finely vast majority respondents of the degree of attitudes towards agricultural innovations (65.7\%) from $10-$ to less than $14 \mathrm{deg}$. The results show that more than half of the respondents are of age from one year or more, that the vast majority of respondents have an education degree, that more than half of them have experience in agricultural work, and that the majority have a degree of attitudes towards agricultural innovations, and this explained to the designers how to preparethe guidance programs necessaryfor these responses in order for farmers to adopt biological control operations in the future for insect pests that affect tomato crops.

\section{RESULTS AND DISCUSSION}

1: Defining the role of agricultural extension in the diffusion and adoption methods of biological control among tomato growers.

The role of agricultural extension was measured using the following five parameters:

1a. Determine the degree to which agricultural extension provides knowledge to farmers about biological control methods and how to use them properly The results in Table 3 show a decrease in the degree of providing knowledge about the methods of biological control from agricultural extension' activities to tomato growers, where the average of all biological control methods is 1.64 and the percentage $41 \%$. As shown in the results of Table 4, the dispersal pheromone ranked first in providing knowledge with an average of 2.38 and a rate of $59.5 \%$, followed bysexattractant pheromones with an average of 1.63 and percentage of $40.75 \%$, pathogenic bacteria with an average of 1.62 and percentage of $40.5 \%$, pathogenic nematodes with an average of 1.33 with percentage $33.3 \%$, then growth regulators and moltinghormones, with an average of 1.29 and percentage $32.4 \%$. It is also shown from the results in Table 5 that more than three-quarters of respondents $(81.74 \%)$ stated that the level of agricultural extension providing knowledge of biological control methods between tomato growers and how to use them in a correct manner was low, while it was found that $15.79 \%$ of them had an average level of residency in turn while $2.47 \%$ had a high degree.

Table-2.Distribution of farmers according to their studied characteristics.

\begin{tabular}{|c|c|c|c|c|c|}
\hline Personal characteristics & Number & $\%$ & Personal characteristics & Number & $\%$ \\
\hline $\begin{array}{l}\text { 1. Age } \\
\text { - less than } 41 \text { years old } \\
\text { - from } 41-\text { to less than } 55 \text { years } \\
\text {-55years and more }\end{array}$ & $\begin{array}{c}177 \\
110 \\
36\end{array}$ & $\begin{array}{l}54.7 \\
34.1 \\
11.2\end{array}$ & $\begin{array}{l}\text { 2. Education degree: } \\
\text { - Illiterate } \\
\text { - Reads and writes } \\
\text { - Intermediate education } \\
\text { - University education }\end{array}$ & $\begin{array}{c}14 \\
66 \\
140 \\
34\end{array}$ & $\begin{array}{l}4.3 \\
20.5 \\
43.3 \\
31.9\end{array}$ \\
\hline $\begin{array}{l}\text { 3. Agricultural tenure: } \\
\text { - Less than } 10 \text { acres } \\
\text { - from } 10 \text { - less than } 15 \text { acres } \\
\text { - } 15 \text { acres and more }\end{array}$ & $\begin{array}{c}23 \\
11 \\
118\end{array}$ & $\begin{array}{c}7.2 \\
34.2 \\
58.6\end{array}$ & $\begin{array}{l}\text { 4. Experience in agriculture: } \\
\text { - less than } 15 \text { years } \\
\text { - from } 15 \text { to less than } 25 \text { years } \\
\text { - } 25 \text { years and above }\end{array}$ & $\begin{array}{c}102 \\
50 \\
171\end{array}$ & $\begin{array}{l}31.6 \\
15.3 \\
53.7\end{array}$ \\
\hline $\begin{array}{l}\text { 5. Area planted with tomato } \\
\text { - less than } 3 \text { acres } \\
\text { - from } 3 \text { to less than } 5 \text { acres } \\
\text { - } 5 \text { acres and more }\end{array}$ & $\begin{array}{c}41 \\
181 \\
94\end{array}$ & $\begin{array}{l}12.6 \\
58.4 \\
29.0\end{array}$ & $\begin{array}{l}\text { 6. Number of years of tomato } \\
\text { cultivation } \\
\text { - less than } 15 \\
\text { - from } 15 \text { to less than } 20 \\
\text { - 20yearsand more }\end{array}$ & $\begin{array}{c}128 \\
82 \\
113\end{array}$ & $\begin{array}{l}39.7 \\
25.5 \\
34.8\end{array}$ \\
\hline $\begin{array}{l}\text { 7. Level of modernization } \\
\text { - less than } 10 \\
\text { - from 10to less than } 14 \\
\text { - } 14 \text { and more }\end{array}$ & $\begin{array}{c}43 \\
108 \\
172 \\
\end{array}$ & $\begin{array}{l}13.8 \\
33.0 \\
53.2 \\
\end{array}$ & $\begin{array}{l}\text { 8. Legree of leadership } \\
\text { - less than } 10 \\
\text { - from } 10 \text { to less than } 14 \\
-1+\end{array}$ & $\begin{array}{c}64 \\
123 \\
136 \\
\end{array}$ & $\begin{array}{l}19.9 \\
38.2 \\
41.9 \\
\end{array}$ \\
\hline $\begin{array}{l}\text { 9. Participation in local development } \\
\text { organizations } \\
\text { - less than } 5 \\
\text { - from } 5 \text { to less than } 10 \\
\text { - } 10 \text { degrees+ }\end{array}$ & $\begin{array}{c}92 \\
140 \\
91 \\
\end{array}$ & $\begin{array}{l}28.4 \\
43.3 \\
28.3\end{array}$ & $\begin{array}{l}\text { 10. Level of informal social } \\
\text { participation } \\
\text { - less than } 10 \\
\text { - from } 10 \text { to less than } 14 \\
\text { - } 14+\end{array}$ & $\begin{array}{c}64 \\
148 \\
111 \\
\end{array}$ & $\begin{array}{l}19.9 \\
45.8 \\
34.3 \\
\end{array}$ \\
\hline $\begin{array}{l}\text { 11. Degree of satisfaction with life in the } \\
\text { region } \\
\text { - less than } 13 \\
\text { - from } 13 \text { to less than } 18 \\
-18+\end{array}$ & $\begin{array}{c}64 \\
101 \\
158\end{array}$ & $\begin{array}{l}19.9 \\
31.2 \\
48.9\end{array}$ & $\begin{array}{l}\text { 12. D Level of attitude towards } \\
\text { agricultural innovations } \\
\text { - less than } 10 \\
\text { - from } 10 \text { to less than } 14 \\
\text { - } 14+\end{array}$ & $\begin{array}{c}51 \\
212 \\
60\end{array}$ & $\begin{array}{l}15.9 \\
65.7 \\
18.4\end{array}$ \\
\hline
\end{tabular}

Note: Total number of respondents was323.

1b. Urging farmers to make a decision to experiment withbiological control techniques by demonstrating their benefits

The results of Table 3 show a decrease in the level of urging farmers to make a decision to experiment withbiological control techniques by demonstrating their benefits, where the average of all biological control methods among tomato growers was 1.54 and the percentage $38.50 \%$. As shown in the results of Table 4 , dispersalpheromones ranked first in the role of extension activities with an average of 2.25 and percentage of $56.25 \%$, 
followed bypathogenic bacteria with an average of 1.44 and percentage of $36 \%$, pathogenic nematodes with an average of 1.38 and percentage of $34.5 \%$, sex attractants with an average of 1.37 and percentage of $34.25 \%$,then growth regulators and moltinghormones with an average of 1.30 and percentage of $32.5 \%$.

It is also shown from the results in Table 5 that the majority of respondents $(83.59 \%)$ said that the degree of agricultural extension to attract farmers to make a decision to experiment with biological control is low, with $14,86 \%$ medium and $1.55 \%$ high.

1c. providing the necessary information for the farmers to implement the biological control process

Data inTable 3show a decrease in the level of agricultural extension activities providing the necessary information to implement biological control methods for tomato growers, with anaverage of 1.57 and a percentage of $39.25 \%$. As shown in the results of Table 4, dispersalpheromones ranked first in the role of this extension activity, with an average of 2.36 and a percentage of 59\%, followed bypathogenic bacteria with an average of 1.53 and percentage of $38.25 \%$, pathogenic nematodes with an average of 1.39 and percentage of $34.75 \%$, sex attractants came with an average of 1.37 and percentage of $34.25 \%$, then growth regulators and moltinghormones with an average of 1.23 and percentage of $30.75 \%$

The results inTable 5 also show that the majority of respondents $(82.66 \%)$ stated that the level of agricultural extension providing the information necessary for farmers to implement biological resistance is low, medium for $15.17 \%$ andhigh for $2.17 \%$.

\section{1d. Providing the necessary capabilities to implement biological resistance}

The results of Table 3 showa decrease in the degree of agricultural extension in providing the necessary capabilities to implement the methods of biological control among tomato growers, with anaverage of 1.57 and percentageof $39.25 \%$.As shown in the results of Table 4, dispersalpheromones ranked first in the role of this extension activity with an average of 2.24 and percentage of $56 \%$, followed by pathogenic bacteria with an average of 1.51 and percentage of $37.75 \%$, sex attractantswith an average of 1.50 and percentageof $37.5 \%$, growth regulators and moltinghormones with an average of 1.36 and percentageof $37.5 \%$, and pathogenic nematodes with an average of 1.17 and percentage of $29.25 \%$.

It also seen from the results in Table 5 that the majority of respondents $(82.66 \%)$ stated that the level of agricultural extension providing the necessary capabilities to implement biological control was low, with $15.17 \%$ average and $2.17 \%$ high.

1e. Helping tomato growers to evaluate the results of applying these methods so that they can take a decision to adopt them

The results of Table 3showa decrease in the level of agricultural extension activities in assisting farmers to evaluate the results of their application of methods of biological control,with an average of 1.52 andpercentage of $38 \%$. As shown in the results of Table 4, dispersalpheromones ranked first with an average of 2.41 and percentage of $60.25 \%$, followed by pathogenic bacteria with an average of 1.44 and percentageof $36 \%$, sex attractantswith an average of 1.42 and percentage of $35.5 \%$, growth regulators and moltinghormones with an average of 1.21 and percentage of $30.25 \%$, and pathogenic nematodes with an average of 1.15 and percentage of $28.75 \%$. It is also seen from the results of Table 5 that the majority of respondents $(84.21 \%)$ stated that the level of agricultural extension assisting farmers in evaluating the results of applying biological control methods and their benefits so that they can make a decision to continue to implement, and in diffusion and adoption, was low, with $14.55 \%$ medium and $1.24 \%$ high. The results presented in Table 3 show that the overall level of the role of agricultural extension in the diffusion and adoption of biological control methods among tomato growers had decreased, with an average capacity of 1.57 and rate of $39.25 \%$. This requires that agricultural extension apparatus works and makes an effort to disseminatemethods of biological control of pests that affect the tomato crop (TotaAbsylota) so that farmers in future can identify them and it becomes part of their routine to eliminatedamage that affects the tomato crop.

Table-3. Distribution of respondents according to the average score of agricultural extension in the process of diffusion and adoption of biological control methods.

\begin{tabular}{l|c|c|c}
\hline Parameters of the role of agricultural extension & Average & Rank \\
\hline $\begin{array}{l}\text { 1- The level of agricultural extension providing knowledge to farmers } \\
\text { and how to use it properly. }\end{array}$ & 1.64 & 41.00 & 1 \\
\hline $\begin{array}{l}\text { 2- The level of agricultural extension providing the necessary } \\
\text { information for implementation. }\end{array}$ & 1.57 & 39.25 & 2 \\
\hline $\begin{array}{l}\text { 3- The level of agricultural extension providing the necessary } \\
\text { capabilities for implementation. }\end{array}$ & 1.57 & 39.25 & 2 \\
\hline $\begin{array}{l}\text { 4- The level of agricultural extension urging farmers to make a } \\
\text { decision to experiment with techniques. }\end{array}$ & 1.54 & 38.00 & 3 \\
\hline $\begin{array}{l}\text { 5- The level of agricultural extension evaluating the results of applying } \\
\text { these methods to making the decision to adopt them. }\end{array}$ & 1.52 & 39.25 \\
\hline $\begin{array}{l}\text { Overall mean of the level of agricultural extension in the role of } \\
\text { agricultural extension in diffusion and adoption of biological resistance. }\end{array}$ & 1.57 & 4
\end{tabular}

Note: Total number of respondents was 323and the maximum score was 4 
Table-4.Distribution of respondents according to the level of the role of agricultural extension in diffusion and adoption of biological control methods by tomato growers.

\begin{tabular}{|c|c|c|c|c|c|c|c|c|c|c|c|}
\hline \multirow[t]{2}{*}{$\begin{array}{l}\text { Agricultural } \\
\text { extension activities } \\
\text { for adoption of } \\
\text { biological control } \\
\text { methods } \\
\end{array}$} & \multirow[t]{2}{*}{$\begin{array}{l}\text { Biological resistance } \\
\text { process }\end{array}$} & \multicolumn{2}{|c|}{$\begin{array}{l}\text { 1- Providing } \\
\text { knowledge ro to } \\
\text { farmers and how } \\
\text { to use it properly }\end{array}$} & \multicolumn{2}{|c|}{$\begin{array}{l}\text { 2- Urging farmers to } \\
\text { make a decision to } \\
\text { experiment } \quad \text { with } \\
\text { techniques }\end{array}$} & \multicolumn{2}{|c|}{$\begin{array}{ll}\text { 3- Providing } & \text { the } \\
\text { necessary } & \\
\text { information } & \text { for } \\
\text { implementation } & \end{array}$} & \multicolumn{2}{|c|}{$\begin{array}{ll}\text { 4-Providing } & \text { the } \\
\text { necessary } & \\
\text { capabilities } & \text { for } \\
\text { implementation } & \end{array}$} & \multicolumn{2}{|c|}{$\begin{array}{l}\text { 5-Evaluating the results of } \\
\text { applying these methods for } \\
\text { making the decision to } \\
\text { adopt them }\end{array}$} \\
\hline & & Average & $\%$ & Average & $\%$ & Average & $\%$ & Average & $\%$ & Average & $\%$ \\
\hline \multirow[t]{7}{*}{$\begin{array}{l}1-\quad \text { Dispersal } \\
\text { pheromones }\end{array}$} & $\begin{array}{l}\text { 1- Depends on creating the artificial smell of female } \\
\text { butterflies }\end{array}$ & 2.38 & 59.5 & 2.47 & 61.75 & 2.4 & 60 & 2.45 & 61.25 & 2.42 & 56.75 \\
\hline & $\begin{array}{l}\text { 2-Spraying it on plants or tying it to its stems in the } \\
\text { form of tubes or rings over a large area. }\end{array}$ & 2.37 & 59.4 & 2.15 & 53.75 & 2.31 & 57.75 & 2.37 & 59.25 & 2.41 & 60.5 \\
\hline & 3- This leads to dispersal of males & 2.40 & 60.00 & 2.05 & 51.25 & 2.33 & 58.25 & 2.19 & 54.75 & 2.37 & 60.25 \\
\hline & $\begin{array}{l}\text { 4- Thus, the chance of mating and laying unfertilized } \\
\text { eggs decreases. }\end{array}$ & 2.39 & 59.75 & 2.20 & 55.00 & 2.5 & 62.5 & 2.21 & 55.25 & 2.37 & 59.25 \\
\hline & $\begin{array}{l}\text { 5- Do not hatch larvae, which will reduce infection } \\
\text { rates }\end{array}$ & 2.38 & 59.50 & 2.40 & 60 & 2.27 & 60.5 & 2.50 & 62.5 & 2.52 & 59.25 \\
\hline & Average & 2.38 & 59.50 & 2.25 & 56.25 & 2.36 & 59 & 2.24 & 56 & 2.41 & 60.25 \\
\hline & Ranking & 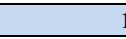 & & & & & & & & & \\
\hline \multirow{6}{*}{$\begin{array}{l}2-\quad \text { Sex- } \\
\text { attractant } \\
\text { pheromones }\end{array}$} & $\begin{array}{l}\text { 1- Depends on creating artificial smell of female } \\
\text { butterflies. }\end{array}$ & 1.63 & 40.75 & .41 & 35.25 & 1.41 & 35.25 & 1.42 & 35.5 & 1.59 & 39.75 \\
\hline & 2- Put it in capsules inside special traps (water/paper) & 1.65 & 41.25 & 1.32 & 33.00 & 1.32 & 33.00 & 1.41 & 35.25 & 1.40 & 35.00 \\
\hline & $\begin{array}{l}\text { 3- Catching male butterflies, the chances of mating } \\
\text { between them also decreases }\end{array}$ & 1.64 & 41.00 & 1.40 & 35.00 & 1.40 & 35.00 & 1.56 & 39.00 & 1.39 & 35.00 \\
\hline & $\begin{array}{l}\text { 4- Leads to laying of unfertilized eggs that do not } \\
\text { hatch larvae }\end{array}$ & 1.63 & 40.75 & 1.35 & 33.75 & 1.35 & 33.75 & 1.61 & 40.25 & 1.32 & 33.00 \\
\hline & Average & 1.63 & 40.75 & 1.37 & 34.25 & 1.37 & 34.25 & 1.50 & 37.5 & 1.42 & 35.5 \\
\hline & Ranking & 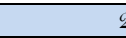 & & & & & & & & & \\
\hline \multirow{6}{*}{$\begin{array}{l}3-\text { Pathogen } \\
\text { ic bacteria }\end{array}$} & 1-The pathogen is used to control pests & 1.73 & 43.25 & 1.60 & 40.00 & 1.58 & 39.50 & 1.42 & 35.50 & 1.38 & 34.50 \\
\hline & 2-The bacteria are in the form of crystals & 1.56 & 39.00 & 1.32 & 33.00 & 1.49 & 37.25 & 1.48 & 37.00 & 1.32 & 33.00 \\
\hline & $\begin{array}{l}\text { 3- Once the insect has eaten these crystals, the } \\
\text { bacterial wall will dissolve }\end{array}$ & 1.54 & 38.5 & 1.47 & 36.75 & 1.45 & 36.25 & 1.56 & 39.00 & 1.65 & 41.25 \\
\hline & $\begin{array}{l}\text { 4- The active substance is released to cause insect } \\
\text { death (especially squamous wings) }\end{array}$ & 1.63 & 40.75 & 1.38 & 34.50 & 1.62 & 40.50 & 1.61 & 40.25 & 1.42 & 35.50 \\
\hline & Average & 1.62 & 40.5 & 1.44 & 36 & 1.53 & 38.25 & 1.51 & 37.75 & 1.44 & 36.00 \\
\hline & Ranking & & & & & & & & & & \\
\hline \multirow[t]{4}{*}{$4-$} & $\begin{array}{l}\text { 1-Kills the insect within } 48 \text { hours, as nematodes breed } \\
\text { on the lesions }\end{array}$ & 1.40 & 35.00 & 1.38 & 34.50 & 1.37 & 34.25 & 1.20 & 30.00 & 1.18 & 29.50 \\
\hline & $\begin{array}{l}\text { 2- Then searches for other pests and so on until these } \\
\text { pests are eliminated }\end{array}$ & 1.26 & 31.50 & 1.39 & 34.75 & 1.41 & 35.25 & 1.15 & 28.75 & 1.12 & 28.00 \\
\hline & Average & 1.33 & 33.25 & 1.38 & 34.5 & 1.39 & 34.75 & 1.17 & 29.25 & 1.15 & 28.75 \\
\hline & Ranking & 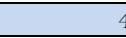 & & & & & & & & & \\
\hline \multirow{5}{*}{$\begin{array}{l}5-\text { Growth } \\
\text { regulators and } \\
\text { molting hormones }\end{array}$} & $\begin{array}{l}\text { 1- Insect molting hormones are used to eliminate } \\
\text { them. }\end{array}$ & 1.30 & 32.5 . & .31 & 32.75 & 1.25 & 31.25 & 1.37 & 34.25 & 1.32 & 33.00 \\
\hline & $\begin{array}{l}\text { 2- Thus, an imbalance occurs in the insect's life and } \\
\text { this leads to its elimination }\end{array}$ & 1.28 & 32.00 & 1.29 & 32.25 & 1.21 & 30.25 & 1.35 & 33.75 & 1.10 & 27.50 \\
\hline & Average & 1.29 & 32.35 & 1.30 & 32.5 & 1.23 & 30.75 & 1.36 & 34.00 & 1.21 & 30.25 \\
\hline & Ranking & 5 & & & & & & & & & \\
\hline & Overall average & 1.65 & 41.27 & 1.55 & 38.7 & 1.58 & 39.4 & 1.56 & 38.9 & 1.53 & 38.15 \\
\hline
\end{tabular}

Note: Total number of respondents was 323 and the maximum score was 4 
The results presented in Table 4 indicate a decrease in the overall level of the role of agricultural extension in the diffusion and adoption of biological control methods among tomato farmers, with an average capacity of 1.57 and a rate of $39.25 \%$, less than the theoretical average.

The results indicate a decrease in the overall level of the role of agricultural extension in diffusion and adoption methods of biological control among tomato growers. This requires the agricultural extension services at the Ministry of Agriculture and Land Reclamation to make considerable efforts to boost the diffusion the study of biological control methods for insect pests that affect tomato crops, among which is the insect Tutaabsoluta, so that farmers continue to use biological control methods and adopt them in the future.

Table-5. Distribution of the respondents according to the role of agricultural extension in the process of diffusionand adoption of biological control methods among tomato growers.

\begin{tabular}{|c|c|c|c|c|c|c|c|c|c|c|}
\hline \multirow{2}{*}{$\begin{array}{l}\begin{array}{l}\text { Agricultural } \\
\text { extension } \\
\text { activities for } \\
\text { adeption }\end{array} \\
\text { Level of } \\
\text { the role } \\
\text { of agricultuxal } \\
\text { extension }\end{array}$} & \multicolumn{2}{|c|}{$\begin{array}{l}\text { 1- Providing } \\
\text { knowledge } \\
\text { farmers and how to } \\
\text { use it properly }\end{array}$} & \multicolumn{2}{|c|}{$\begin{array}{l}\text { 2- Urging farmers } \\
\text { to make } \\
\text { a decision to } \\
\text { experiment with } \\
\text { techniques }\end{array}$} & \multicolumn{2}{|c|}{$\begin{array}{l}\text { 3- Providing the } \\
\text { necessary } \\
\text { information for } \\
\text { implementation }\end{array}$} & \multicolumn{2}{|c|}{$\begin{array}{l}\text { 4-Providing the } \\
\text { necessary for } \\
\text { capabilities for } \\
\text { implementation }\end{array}$} & \multicolumn{2}{|c|}{$\begin{array}{l}\text { 6- Evaluating the } \\
\text { results } \\
\text { of applying these } \\
\text { methods for making the } \\
\text { decision } \\
\text { to adopt them }\end{array}$} \\
\hline & Number & $\%$ & Number & $\%$ & Number & $\%$ & Number & $\%$ & Number & $\%$ \\
\hline $\begin{array}{ll}\text { Low level (less } \\
\text { than } 34)\end{array}$ & 264 & 81.74 & 270 & 83.59 & 267 & 82.66 & 267 & 82.66 & 272 & 84.21 \\
\hline $\begin{array}{l}\text { Moderate level ( } 34 \\
\text { to less than 51) }\end{array}$ & 51 & 15.79 & 48 & 14.86 & 49 & 15.17 & 49 & 15.17 & 47 & 14.55 \\
\hline High level $(51+)$ & 8 & 2.47 & 5 & 1.55 & 7 & 2.17 & 7 & 2.17 & 4 & 1.24 \\
\hline Total & 323 & 100 & 323 & 100 & 323 & 100 & 323 & 100 & 323 & 100 \\
\hline
\end{tabular}

\subsection{Level ofthe Role of Agricultural Extension in the Process of Diffusionand Adoption of Biological Control Methods among Tomato Growers}

The results in Table 6 show that the majority of respondents $(82.97 \%)$ stated that the level of the role of agricultural extension in diffusion and adoption of biological control methods among tomato growers was low, while $15.17 \%$ of them mentioned average and $1.86 \%$ high.

This explains that the Central Administration for Agricultural Extension of the Ministry of Agriculture should conduct awareness seminars on the importance of biological control of tomato crop pests in working on elimination of those insect pests, including Tutaabsoluta, to promote the production of tomato crops.

Table-6. Distribution of respondents according to the level of agricultural extension in the process of diffusion and adoption of biological control methods.

\begin{tabular}{|c|c|c|}
\hline Level & Number & $\%$ \\
\hline Low (less than 170) & 268 & 82.97 \\
\hline Average (170 to less than 255 ) & 49 & 15.17 \\
\hline $\operatorname{High}(255+)$ & 6 & 1.86 \\
\hline Total & 323 & 100 \\
\hline
\end{tabular}

Note: Total number of respondents was 323 .

5.2. Defining the relationship between the level of the role of agricultural extension in diffusion and adoption methods of biological control among tomato growers, and selected independent variables

Regarding the relationship between the role of agricultural extension in diffusion andadoption methods of biological control among tomato growers, and between some independent variables, the statistical hypothesis was formulated that "There is no relationship between the degree of the role of agricultural extension in diffusion and adoption methods of biological control among tomato growers and the following independent variables:age,education,agricultural tenure, number of years of agricultural work experience, area planted with the tomato crops,number of years of tomato cultivation,level of modernization,level of leadership, participation in local development organizations, level of informal social participation, level of satisfaction with life in the region, and level of attitude towards innovations, by testingthe validity of the hypothesis using the simple correlation coefficient of Pearson $(r)$."

1- There is a direct correlation at the level of significance of 0.01 between the following independent variables: participation in local development organizations, level of informal social participation, level of satisfaction with life in the region, and level of attitudetowards innovations as the value of $r$ calculated for each separately. The results inTable 7 show, respectively, 0.395**, 0.397**, $0.357^{* *}$, and $0.416^{* *}$, and there is a direct correlation at the level of significance 0.05between these independent variables: level of education andlevel of modernization, where the values of $r$ were, respectively, $0.192 *$ ando.193*. 
2- There is an inverse significant relationship at the level of significance 0.01 between these variables: age where $r$ reached $-0.248^{*}$, and an inverse significant relationship at the level of significance 0.05 with these variables:agricultural tenure, number of years of agricultural work experience, and area cultivated with tomato crops, where the values of $r$ were, respectively, $-0.189^{*},-0.191^{*}$, and $-0.185^{*}$.

3- There is no significant relationship between each of these independent variables: number of years of tomato cultivation andlevel of leadership, where the values of $r$ were, respectively, 0.106 and 0.153 . Thus, we can reject the statistical hypothesis.

Thus, the statistical assumption states that "There is no correlation between the degree of the role of agricultural extension in diffusion and adoption of biological control methods among tomato growers, and the following independent variables: age, level of education, area of agricultural tenure, number of years of experience in agricultural work, area planted with tomato crop, level of modernization, participation in local development organizations, level of informal social participation, level of satisfaction with life in the region, and level attitude toward agricultural innovations".

We were unable to reject the statistical assumptions for the remainder of the studied variables - number of years of tomato cultivation and level of leadership.

Table-7. Correlation coefficients for the relationship between the level of agricultural extension role in diffusion and adoption methods of biological control among tomato growers and some independent variables.

\begin{tabular}{|c|c|c|}
\hline $\mathbf{M}$ & Independent variables & $\begin{array}{c}\text { Pearson simple correlation } \\
\text { coefficient }(r)\end{array}$ \\
\hline 1 & - Age & $-0.248^{* *}$ \\
\hline 2 & - Level of education & $0.192^{*}$ \\
\hline 3 & - Agricultural tenure & $-0.189^{*}$ \\
\hline 4 & - Number of years of agricultural work experience & $-0.191^{*}$ \\
\hline 5 & - Area planted with tomato crop & $-0.185^{*}$ \\
\hline 6 & - Number of years of tomato cultivation & 0.106 \\
\hline 7 & - Level of modernization & $0.193^{*}$ \\
\hline 8 & - Level of leadership & 0.153 \\
\hline 9 & - Participation in local development organizations & $0.395^{* *}$ \\
\hline 10 & - Level of informal social participation & $0.397^{* *}$ \\
\hline 11 & - Level of satisfaction with life in the region & $0.357^{* *}$ \\
\hline 12 & - Level of attitudetowards innovations & $0.416^{* *}$ \\
\hline
\end{tabular}

\subsection{Applied Benefits}

1. The results of this research contribute to providing a picture of the current situation for officials of the Ministry of Agriculture when planning and implementing extension programs.

2. The research uses a methodology to enhance the agricultural extension services provided to farmers in the biological control of tomato diseases.

3. This research documents the importance of disseminating the methods of biological control of tomato diseases so that farmers can adopt such methods.

Funding: This study received no specific financial support.

Competing Interests: The authors declare that they have no competing interests.

Acknowledgement: All authors contributed equally to the conception and design of the study.

Views and opinions expressed in this study are those of the authors views; the Asian Journal of Agriculture and Rural Development shall not be responsible or answerable for any loss, damage, or liability, etc. caused in relation to/arising out of the use of the content.

\section{REFERENCES}

Abdou, O., Mohammed, Y. A., \& Allam. (2016). International Journal of Pharm Tech Research, 9(12), 357-372.

Al-Huneidi, Ahmed, H., \& Fayyad, Y. H. (2004). Bio-control of insect pests. Ministry of Agriculture and Land Reclamation in Cairo, Agricultural Research Center, Central Administration for Agricultural Extension, Bulletin No. 900.

Bahloul, A. Q. (1999). The effect of chemical technology on the continuous agricultural development in Egypt. Paper presented at the The Seventh Conference Of Agricultural Economists, Egyptian Technology And Agriculture In The Twenty-First Century, Egyptian Society for Agricultural Economics, from 28-29 July.

Central Administration of Agricultural Economics. (2018). Ministry of agriculture and land reclamation. Egypt: Central Administration of Agricultural Economics.

Central Agency for Mobilization and Statistics. (2015). Retrieved http://www.capmas.gov.eg/Pages/Publications.aspx?page_id=5104.Egypt. Visited in2015.

Egyptian Plant Pathology Society. (1996). Genetic engineering and plant pathology. Cairo: Egyptian Plant Pathology Society.

Flegel. (1990). Extension and technology adoption in agricultural extension. Burton Swanson, Agricultural Extension - A Guidebook, Food and Agriculture Organization. 
Hamdi, Y. A. (2006). Organic Agriculture in Egypt, the eighth conference of the Scientific Association for Agricultural Extension, the role of agricultural extension in the development of Egyptian exports. Cairo: The Egyptian International Center for Agriculture.

International Potato Center. (2015). Retrieved from: https://cipotato.org/. Visited in 2015.

Krejcie, R. V., \& Morgan, D. W. (1970). Determining sample size for research activities. Educational and Psychological Measurement, 30(3), 607610.Available at: https://doi.org/10.1177/001316447003000308.

Matrouh Governorate. (2016). Tourist guide. 4.

Omar, A. M. (1992). Contemporary Agricultural Extension. Cairo: Egypt for Scientific Services.

The Arab Republic of Egypt. (2018). Ministry of agriculture and Land reclamation. Agriculture Directorate, Matrouh Governorate, Unpublished Data.

Tolba, A. R. F. (2008). Definition of organic agriculture and its organized laws. Atraining Course in Organic Farming, the Central Laboratory of Organic Agriculture in Conjunction with CAIRE International in Egypt.

Yousria, A., Allam, A., O., \& Mohamed. (2016). Agricultural extension needs' assessment of bedouin farmers for wheat and barley crops under adverse environmental conditions in North Sinai Governorate- Egypt. International Journal of ChemTech Research, 9(9), 62-74. 